\title{
Grouper Fish Fisheries in Bays of Kwandang, Gorontalo Province are reviewed from Economic Social Aspects
}

\author{
Dewi Shinta Achmad ${ }^{1}$, Syamsu Alam $\mathrm{Ali}^{2}$, Sudirman $^{3}$ and Yusran Nur Indar ${ }^{4}$
}

${ }^{1}$ Doctoral Program of Agriculture Science, Hasanuddin University, Makassar, Indonesia.

${ }^{1}$ Aquaculture Study Program, Muhammadiyah University, Gorontalo, Indonesia.

Email: dewishintaachmad@gmail.com

${ }^{2}$ Faculty of Marine and Fishery Science Study Program of Marine Science, Hasanuddin University, Makassar, Indonesia Email: syamsualam.ali@gmail.com

${ }^{3}$ Faculty of Marine and Fishery Science Study Program of Marine Science, Hasanuddin University, Makassar, Indonesia Email: sudiru2002@yahoo.com

${ }^{4}$ Faculty of Marine and Fishery Science Study Program of Marine Science, Hasanuddin University, Makassar, Indonesia Email: ourmarine@yahoo.com

\begin{abstract}
Socio-economic information is needed in the formulation of responsible grouper management. This study aims to determine the socio-economic conditions of grouper fishermen in Bays of Kwandang. This research was conducted from January to July 2018. Primary data was collected through surveys and direct interviews with fishermen and fishermen figures.. The Collecting data using questionnaire assistance on 35 people respondents. Grouper fishermen in Bays of Kwandang were still in the category of traditional fishermen. The income of fishermen is below of Rp. 200,000/trip with the catch per trip less than $25 \mathrm{~kg}$. To improve welfare, fishermen need subsidies from the local government. The subsidies are in form of fishing fleets and capital to develop business diversification in the fisheries sector.
\end{abstract}

Keywords-Grouper fish, socio-economic, and bays of kwandang.

\section{INDRODUCTION}

Bays of Kwandang is one of the main bases of fishing activities in the Sulawesi Sea (Faizah et al., 2014). There are three fishing efforts, namely large (Rahmat, 2007)small pelagic (Faizah et al., 2014), and demersal (Fahmi and Adrim, 2002) in the area . Of the various types of fish caught, groupers are one of the most dominant fish and have high economic value. Market demand for live groupers, both at domestic and abroad is very high (Kristanto et al., 2015).

To meet domestic and export market needs, the fishing of grouper is carried out on a large scale (Mujiyanto and Sugianti, 2014). More intensive exploitation of groupers occurs because of the high economic benefits (Ramadhani et al., 2017). The intensive fishing leads to overexploitation (Santoso, 2016). Sustainable management is needed to anticipate problems. Regarding sustainable management, the socio- economic conditions of grouper fishermen need to be known. Therefore, a study was conducted to determine the socio-economic conditions of grouper fishermen in Bays of Kwandang.

\section{MATERIALS AND METHODS}

The research was conducted from January to July 2018, in Bays of Kwandang. Sample collection areas consisting of three islands, namely Pulau Malambe, Dudepo, and Ponelo. Primary data collected through surveys and direct interviews with fishermen and fishermen figures. Questionnaires arranged to collect data as modifications of Lorwens \& Wouthuyzen (Lorwens and Wouthuyzen, 2015) (Table 1). The distribution of respondents in this study were 15 people in Malambe Island, 10 people in Dudepo, and 10 people in Ponelo.

Table 1. Questionnaires

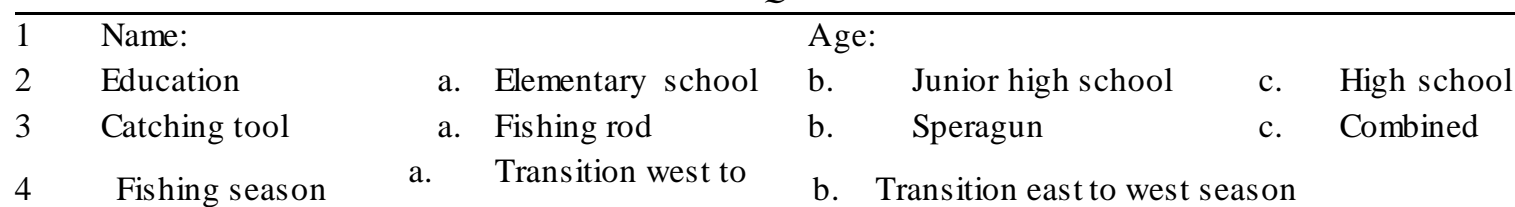




\begin{tabular}{|c|c|c|c|c|c|}
\hline 5 & Arrest fleet & $\begin{array}{ll} & \text { east season } \\
\text { a. Without engine }\end{array}$ & b. & Machine & \\
\hline 6 & Target of arrest & a. Pelagic fish & b. & Coral fish & c.Combined \\
\hline 7 & Long sail & a. One day fishing & b. & $>1$ day & \\
\hline 8 & Range collaps & a. Far & b. & Permanent & c.Close \\
\hline 9 & Mileage & a. $<5$ miles & b. & 5-10 miles & c.> 10 miles \\
\hline 10 & Traveling time & a. $<1$ hour & b. & 1-2 hours & c. $>2$ hours \\
\hline 11 & Size of fish & a. Smaller & b. & Permanent & c.Big \\
\hline 12 & Catch & a. $<25 \mathrm{~kg}$ & b. & $25-50 \mathrm{~kg}$ & c. $>50 \mathrm{~kg}$ \\
\hline 13 & Subsidy & a. Really need & b. & Not really needed & c.No need \\
\hline 14 & Handling & a. Consumption & b. & Sell & c.Processed \\
\hline 15 & Expected assistance & a. Catching tool & b. & Capital & c.ship \\
\hline 16 & Income / trip & a. $\quad<$ Rp. 200,000 & b. & Rp. $200,000-400,000$ & c.> Rp. 400,000 \\
\hline 17 & Amenities & a. Ice factory & b. & First time & c.Cooperative \\
\hline
\end{tabular}

\section{RESULTS AND DISCUSSION}

Bays of Kwandang is one of the centers of capture fisheries in North Gorontalo Regency. At the beginning of 2011, the Kwandang Fishery Port has been built at whose position on the edge of the Sulawesi Sea. The port is the main base of reef fish fisheries. The economically important reef fish that are caught in Bays of Kwandang are five species. The species are mud grouper fish (Epinephelus coioides ), tiger grouper (Epinephelus fuscoguttatus), rat grouper (Cromileptis altivelis), sunu grouper (Plectropomus leopardus), and moon tail grouper (Variola albimarginata). The fish were caught by stretching, fish trap, and speargun.
Based on the survey and interviews of social aspects, the highest percentage of grouper fishermen age is 30- 40 years $(49 \%)$. Then followed by more than 40 years $(29 \%)$ and under 30 years (23\%) (Figure 1a). The majority of fishermen's education only elementary school with a percentage of $57 \%$ followed by junior high school with a percentage of $29 \%$, and high school only $14 \%$ (Figure 1b). The low an educational level of fishermen is caused by two factors. The factors are the lack of awareness of the community island about the importance of education and the difficult access to schools that very far from the fishermen's settlements.

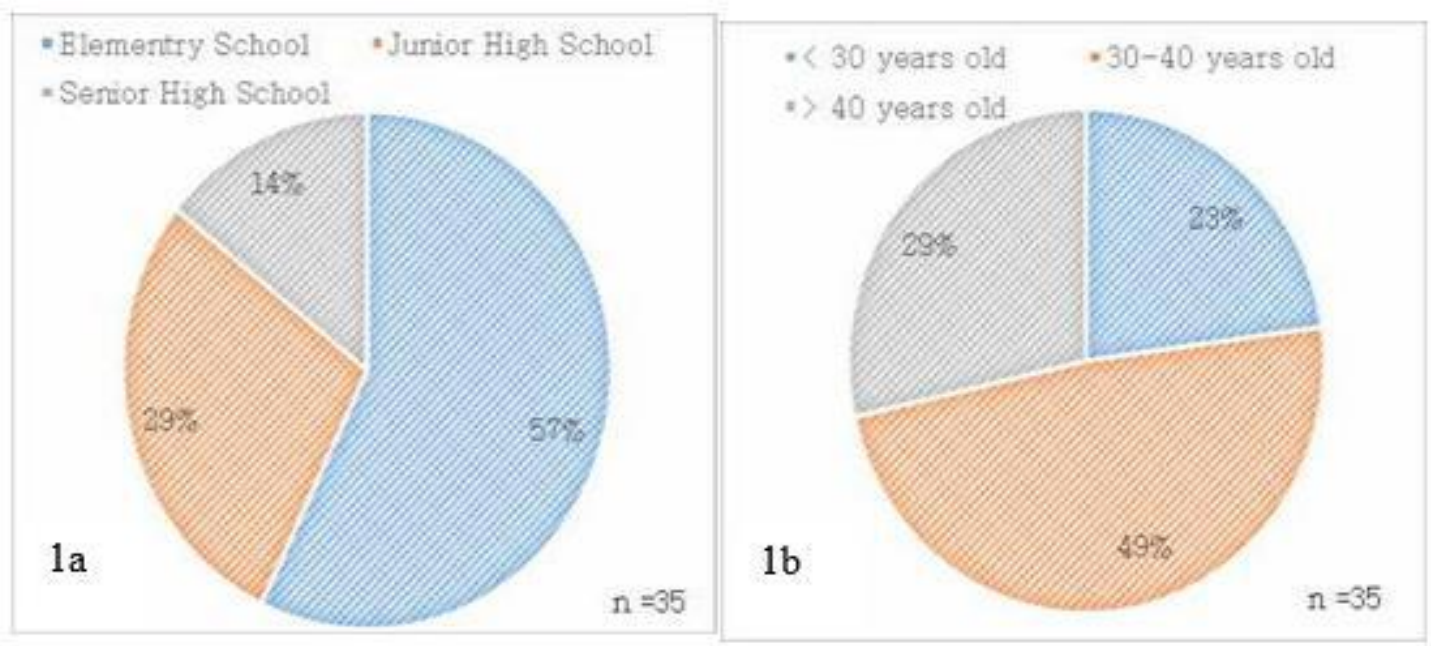

Fig.1: The age (a) and educational level offishermen in Bays of Kwandang, Gorontalo Province

Based on the of fishing gear and fishing area aspects, fishermen in Bays of Kwandang are traditional fishermen category. The fishing gear used in the area are fishing rods with a percentage of $54 \%$, speargun $40 \%$, and a combination of the two fishing gear at $6 \%$ (Figure 2a). District Marine and Fisheries of North Gorontalo reported in 2017 that the catch of mud groupers used stretch fishing rods is 74,2 tons, sunu grouper 61,8 tons, and rat grouper 
24, 7 tons. Thus, the catch of speargun fishing gear is mud grouper fish of 47.5 tons. All grouper fishermen in Bays of Kwandang have used boats with 5.5-15 HP engine capacity (Figure 2b). The engine is a small engine capacity category that use to cover a distance to the fishing area (fishing ground ) as far as below of 5 miles (Figure 2c).

The grouper fishing area in Bays of Kwandang is concentrated in several locations such as around Mohinggito Island, Malambe Island, Saronde Island, and the most remote one is Lampu Island. The areas are directly next to the Sulawesi Sea. As many as $91 \%$ of fishermen said that the travel time needed to get to the farthest fishing ground (Pulau Lampu) was around 45 minutes to 1 hour. Thus, only $9 \%$ of fishermen needed 1 2 hours to get to fishing ground (Figure 2d). Therefore, the operation length of grouper fishermen is only around 12 hours/trip (one-day fishing) (Figure 2e). Furthermore, $94 \%$ of grouper fishers in Bays of Kwandang make arrests in the eastern season and only $6 \%$ also make arrests in the western season (Figure 2f). The fishermen decision based on oceanographic conditions such as strong currents and bad weather and the limitations of adequate fishing facilities (Achmad et al., 2017; Yulianto et al., 2013).

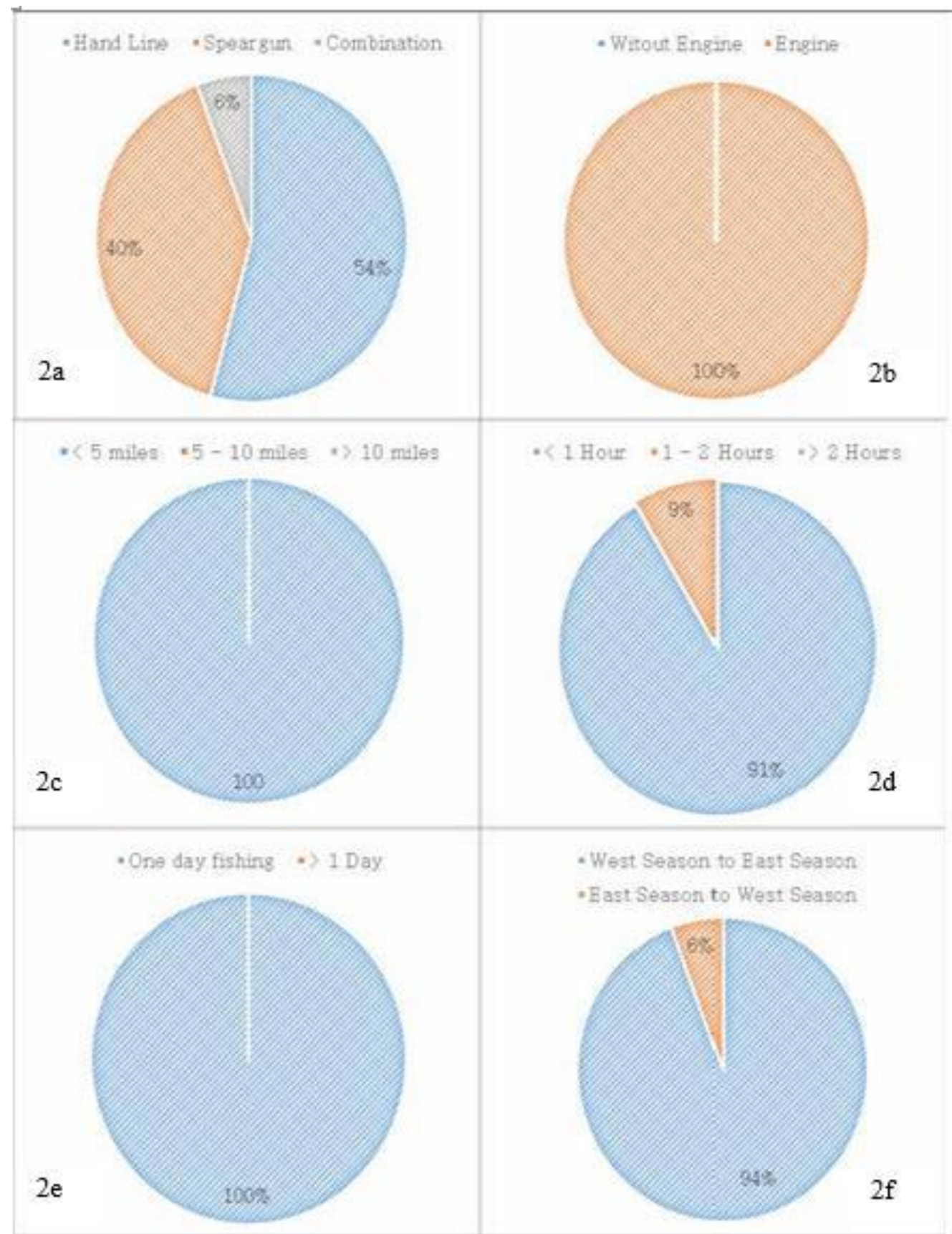

Fig.2: The Types of fishing gear (a), Capture fleet (b), Distance to fishing ground (c), Travel time to fishing ground (d), Length of sea (e), and Season of grouperfishing $(f)$ in Bays of Kwandang, Gorontalo Province. 
The survey and interview revealed that $86 \%$ of the distance of fishing ground was increased while only $14 \%$ said it remained (Figure 3a). In the last few years, the fishing ground has shifted somewhat to the outer islands. Before that time, catch activity of fishermen only in around of Mohinggito Is land and Malambe Island. The islands are close to their settlements. However, it is currently shifting far to Saronde Island and Lampu Island. The shift in the fishing ground was also followed by the increasing number of small-sized fish caught $(71 \%)$ while only $29 \%$ of fishermen said the size of the caught fish did not change (Figure 3b)

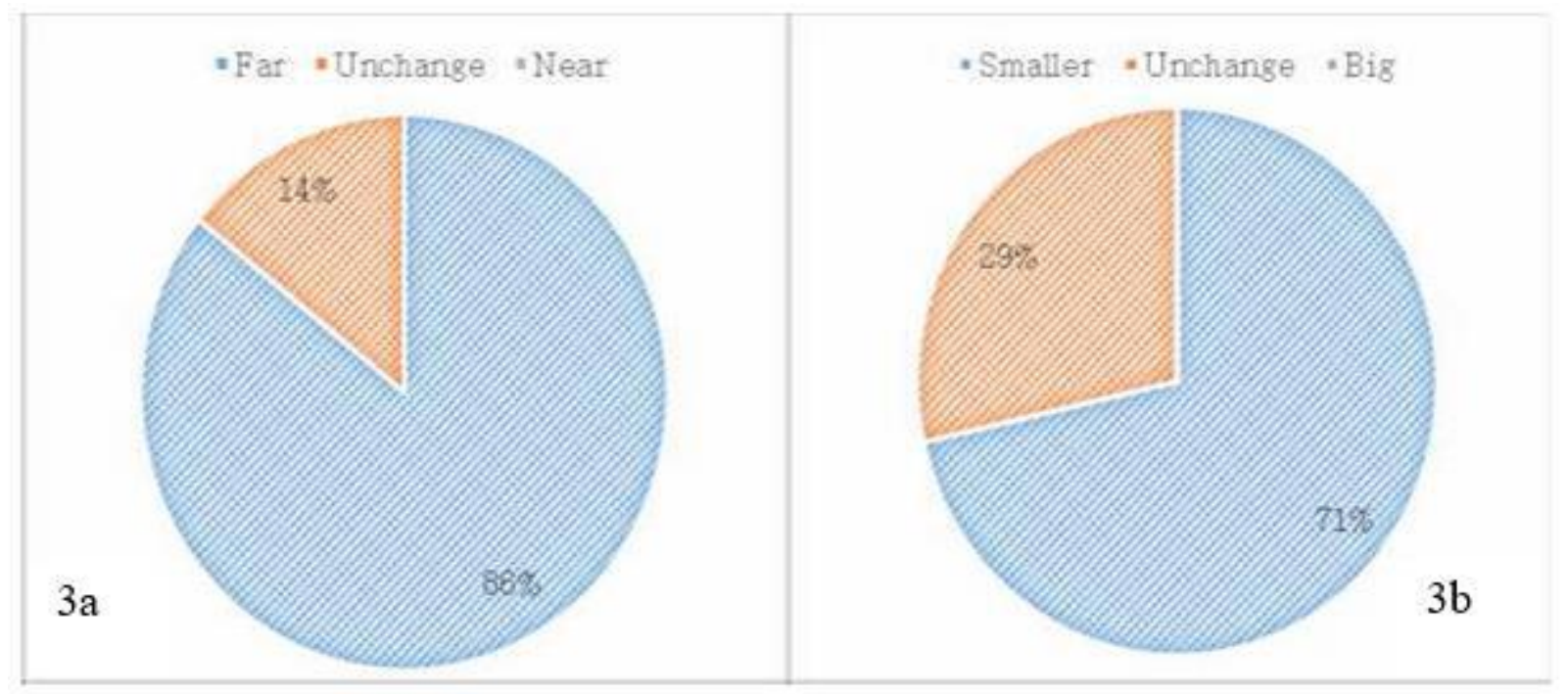

Fig.3: The Range collaps (a) and (b) Fish size in Bays of Kwandang, Gorontalo Province

The results of surveys and interviews for economic aspects show that the majority of grouper fishermen have income below Rp. 200,000/trip (54\%), Rp. 200,000400,000/trip

(40\%), only a small portion of the income is above Rp. 400,000 trip (6\%) (Figure 4a). While the monthly expenditure of fishermen is mostly above Rp. 2,500,000 $(66 \%)$, and other fishermen have in the range of Rp. 1,500,000- Rp.2,500,000 (34\%) (Figure 4b). The high expenditure of fishermen is sometimes not accompanied by the amount of catch obtained. Percentage of catch per trip shows that $69 \%$ of fishermen obtained catches below $25 \mathrm{~kg} /$ trip, $26 \%$ in the range of $25-50 \mathrm{~kg} /$ trip, and only $6 \%$ above of $50 \mathrm{~kg} /$ trip (Figure $4 \mathrm{c}$ ). The catch of $96 \%$ of fishermen is directly sold to collectors and $6 \%$ for selfconsumption (Figure 4d).

The survey results also revealed that fishermen need subsidies from the local government (Figure 4e). The subsidies needed are capture fleets (86\%), fishing gear
(3\%), and capital assistance (11\%) (Figure 4f). So far, many fishermen have spent funds to repair their fleet catches. The capture fleet that has a more distance travel capacity enables fishermen to expand into the open sea which has been exploited so far. Besides, the capital assistance help to develop business diversification in the fisheries sector.

Facilities needed by fishermen in Bays of Kwandang are ice factories (51\%), Fuel stations (46\%), and cooperatives institutions (3\%) (Figure 5). The access collectors away from fishing ground cause the fish catches sometimes not so fresh that it affects the price of fish. With the existence of an ice factory on the is lands around the fishing ground, the quality or freshness of the fish can be maintained. Fishermen also need the fuel stations around the is land to guarantee the availability of fuel. So far the fuel for fishing boats has been obtained from traders around the Kwandang Fishery Port and the price reaches Rp. 10,000/liter while the normal price is only Rp. 8,000/liter. 


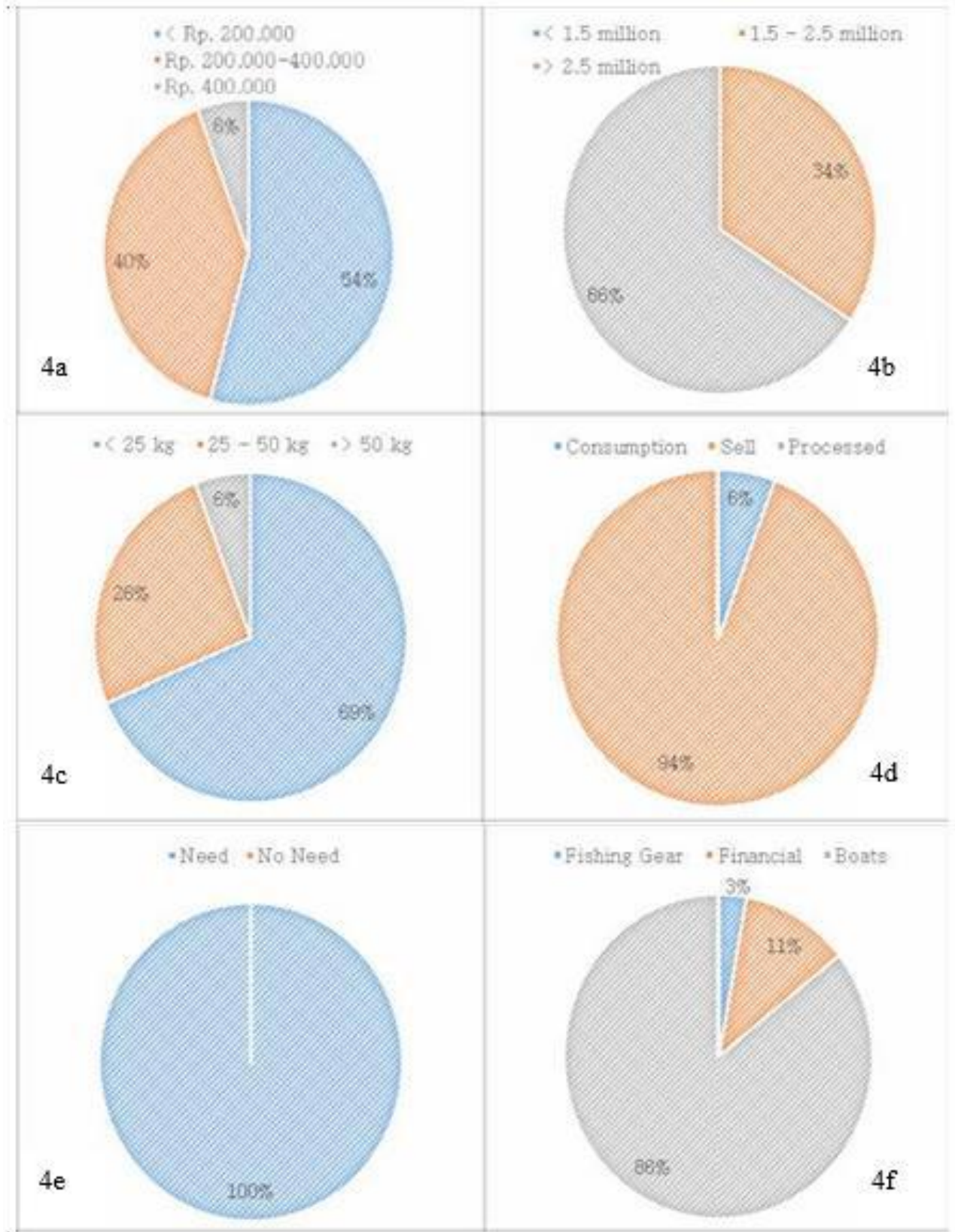

Fig.4: The Fishermen's income per trip (a), monthly fishermen's expenditure (b), one-trip catch (c), handling of catches (d), fishermen who need subsidies (d), and assistance expected by fishermen ( $f$ ), in Bays of Kwandang, Gorontalo Province.

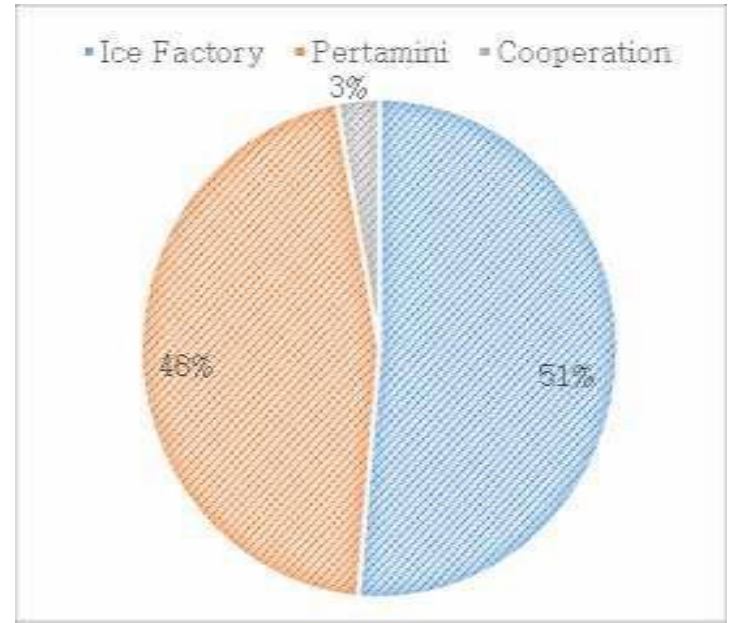

Fig.5: facilities needed by fishermen in Bays of Kwandang, Gorontalo Province. 
IV. CONCLUSIONS AND RECOMMENDATIONS

Grouper fishermen in Bays of Kwandang are a traditional fishermen category who income below Rp.

200,000/trip and less than $25 \mathrm{~kg}$ catch/trip. To improve welfare, fishermen need subsidies from the local government like fishing fleets and capital to develop business diversification in the fisheries sector.

\section{ACKNOWLEDGMENT}

The author would like to express his gratitude to the Directorate of Research and Community Service of the Directorate General of Research and Development for research funding assistance through the doctoral dissertation research scheme.

\section{REFERENCES}

[1] Achmad, D., Nurdin, M., Ridwan, Selle, Y., Gobel, H., 2017. Analysis of Volume of Grouper Traffic (Serranidae) Based on Certification Approach in Gorontalo Province. Academics 6, 84-90.

[2] Fahmi, Adrim, M., 2002. Demersal Fish Fauna in Kwandang Bay, Kwandang District, Gorontalo Regency, North Sulawesi. Biol. Environ. Oceanogr. Indones. Inst. Sci. 19-24.

[3] Faizah, R., Sadiyah, L., Hariati, T., 2014. Population and Biological Reproductive Parameters of Bentong (Selar crumenophthalmus) Fish in Kwandang Waters, North Gorontalo. Bawal 6, 111- 117.

[4] Kristanto, A., Giri, I., Sutarma, T., 2015. Study of Hybrid Grouper Cultivation Development Model in East Lombok, West Nusa Tenggara, in: Proceedings of the 2015 Aquaculture Technology Innovation Forum. pp. 893-899.

[5] Lorwens, J., Wouthuyzen, S., 2015. SocioEconomic Study, Efforts and Expectations of Coral Fishers in Increasing Productivity and Income in Biak-Numfor Regency, Papua, in: National Symposium on Indonesian Sustainable Coral Fisheries Management. Bali, pp. 222-241.

[6] Mujiyanto, Sugianti, Y., 2014. Bioecology of Grouper in Karimunjawa Islands. Ocean Sci. 19, 8896.

[7] Rahmat, E., 2007. Large Pelagic Catching Techniques Using Funai Fishing Equipment (Mini Pole And Line) In Kwandang, Gorontalo Regency. BTL. 5, 69-74.

[8] Ramadhani, A., Muchlisin, Z., Sarong, M., Coal, A., 2017. Relationship of long weight and factors of grouper condition of Serranidae family caught in Pulo waters in Aceh Besar District, Aceh Province. Depik. 6, 112-121.

[9] Santoso, D., 2016. Sustainable Potential and Status of Utilization of Red Snapper and Grouper Fish in the Alas Strait of West Nusa Tenggara Province. J. Trop. Biol. 16, 15-23.

[10] Yulianto, I., Wiryawan, B., Taurusman, A., Wahyuningrum, P., Kurniawati, V., 2013. Dynamics of Grouper Fisheries in Karimunjawa National Park. Mar. Fish. 4, 175-181. 